\title{
WHAT WE TALK ABOUT WHEN WE TALK ABOUT STYLE
}

Mary Stefaniak, award winner

WHEN WE TALK about fiction at the Writers' Workshop, we don't talk much about language. We complain if a character is flat or unmotivated or "not fully realized." We yawn if the pace is too slow, get nervous if things move too quickly, and occasionally debate about what a story means. We leap at the chance to point out suspicious shifts in point-of-view. But apart from noting misspelled words, outright awkwardness and ambiguity or, less frequently, the need to tighten a wordy passage, we don't seem to consider the role of language in our own fiction. We just don't talk about the way the structure of sentences and the choice of words and details create the tone, control the pace, and give the work the energy that makes us say, rather vaguely, that the author really brought this scene or that character to life. We might notice that the sentences are monotonously uniform in length or that too many of them start with "she," but we seldom examine the way the juxtaposition of certain words creates the tension in a passage or the way the rise-and-turn-and-fall of a sentence can mirror the movement of an entire story. And we certainly don't look at punctuation, unless it's distracting-like those terrible dashes (and parentheses) we've been taught to object to- or downright incorrect.

The subject of how language works in a piece of fiction, how the words chosen and their arrangement create the only vision of a writer's world that we as readers are permitted to see, rarely comes up in workshop. Why not? Because it's hard to talk about. For at least two reasons.

The first reason is that many of us are not equipped to discuss matters of diction and syntax and even punctuation. In our own work, we operate intuitively (for better or worse) in regard to such things. When it comes to discerning their role on the page before us, we're 
stuck. We don't know the rules. We don't have the vocabulary. We can read a Raymond Carver story and say the sentences are, for the most part, shorter and simpler than the sentences in a John Cheever story. Maybe we can even go so far as to say that there is a spareness in Carver's style. But what if some argumentative soul plucks this forty-seven-word sentence from "Why Don't You Dance?" in What We Talk About When We Talk About Love:

They got out of the car and began to examine things, the girl touching the muslin cloth, the boy plugging in the blender and turning the dial to MINCE, the girl picking up a chafing dish, the boy turning on the television set and making little adjustments.

What happens then to our claim that Carver writes short, simple sentences? Most likely, we shrug and cite the exception to every rule. We might, if pressed, notice that this particular sentence has pretty much the same effect as it would have if it were five little sentencesthe first ending with "things" and the rest beginning with either "the boy" or "the girl." But if one among us tried to account for the effect by explaining that after the independent clause "They got out of the car and began to examine things," the sentence consists of a series of absolute phrases, each one parallel to the others in structure and differing from a complete sentence only in its lack of the auxiliary verb "to be," so that the total effect is exactly that of a series of short, simple, complete actions rather than an impression of sentence complexity-if one of us tried to say that - the rest of us would look confused, impressed, or irritated, and finally bored. After all, we might say, we are writers, not grammarians.

And we would have a point. Knowing the names of the parts of speech doesn't help us use them any more effectively. But it does help us talk about them when they're on the page. Not having the vocabulary to speak confidently about certain elements of a writer's style-his characteristic syntax and punctuation patterns-we tend to speak in workshop of other things.

But there is another more telling reason why we slight the role of language, particularly in the discussion of our own work. To talk about the language in a passage is to talk about its diction, its syntax, its use of figurative language - to talk, in other words, about style, as in Carver's "spare" style and Cheever's "effusive" one. It's fairly easy to find adjectives to characterize those two writers, but how much harder it is to describe the style of writers in the workshop. We come up with "traditionalist" or "minimalist" or "loose and rambling" (maximalist?). The problem is that many of us, at this early stage in our writing lives, don't have a very distinctive writing style. And the problem runs deep; writers write the way they do because they see the world the way they do. Their vision determines their style. Vision is hard to come by. 
The writer's vision determines what she will choose to write about, how much distance she will maintain between herself and the world of her fiction-and how close she will let the reader get to it-what words she will use and how she will arrange them into sentences to create her world on the page. Her "style" reveals her stance toward the world; presents it rich in detail or laid bare, clean to the bone; puts rose-or blue or sepia-colored glasses on the reader or requires that we view the fictional world in gray or unequivocal black and white.

Style, in other words, is the writer's vision of the world made manifest in the choice of words, the inclusion or exclusion of detail and metaphor, the structure of sentences.

Look again at Raymond Carver. Here is a passage about the same boy and girl:

He lay down on the bed and put the pillow under his head.

"How does it feel?" she said.

"It feels fine," he said.

She turned on her side and put her hands to his face.

"Kiss me," she said.

"Let's get up," he said.

"Kiss me," she said.

She closed her eyes. She held him.

He said, "I'll see if anybody's home."

Now there's a classic early Carver passage; not only are the sentences short and choppy, not only are all the clauses simple subject/verb arrangements, not only does every clause outside the dialogue begin with "he" or "she," but there is not a single prenominal adjective (never: "the firm bed" or "his smooth face"), not an adverb (never: "he lay down carefully"), not a single modifying phrase (never: "she said, giggling" or "She turned on her side, her hair falling across her face").

And why not? Why this utter lack of nonrestrictive modifiers, as our grammarian friend would call such phrases? Precisely because Carver's vision requires it. There are no nonrestrictive modifiers in Carver's prose here because there are no nonrestrictive details in his world. As Carver sees it, all details must restrict the meaning of an action. If they don't, they are not worth mentioning. More to the point, in Carver's fictional world, they do not exist. The girl's hair does not fall across her face because it is not necessary that it do so. It adds no shade of meaning-or, worse, the wrong shade of meaning. Such a detail distracts us from the austerity of the moment, from the brutal emptiness of human relationships as Carver sees them in this story. The vividness of such a detail as the girl's hair falling or the boy's skin feeling smooth to her hand might even fool us into thinking there is a sensuousness to this moment on the bed.

Rich textures and sensuousness are not part of Carver's vision in 
What We Talk About. So they are not part of his prose style either. Style is vision made manifest.

Anne Beattie is another writer known for the simplicity-critics might say the paucity-of her style. In Beattie we find the same repetition of words and structures (like a 17-sentence paragraph at the end of "Shifting," in which 13 sentences begin with "She"), the same rare appearance of figurative language and nonrestrictive details (although these are not as rare as they are in Carver). Like Carver, Beattie allows her reader to see only this moment when these (usually two) characters (usually fail to) come together. The rest of the worldthe extraneous sounds, sights, smells, textures of life-is excluded from the fictional world because, for the most part, her characters lead emotionally barren lives. Her vision, at least in Secrets and Surprises, is one of isolation and fragmentation: there is only this one (usually poor) moment for us to live through, with no larger meaning for our existence and little hope of connection with anyone else. Her prose style creates this vision through the remarkable leveling force of her sentences. All things, people, details are made equal in a series of short, simple structures. In this passage from "A Reasonable Man," the beef stew gets as much attention as the main character's neurotic inability to leave her apartment:

"Didn't you go out today?" the man asks.

"No. I didn't go anywhere. I didn't have anywhere to go."

"But you went out yesterday, I presume."

"Yesterday?" (She is not a good liar.)

He nods again.

"I don't think I went out yesterday. No."

He sighs heavily. Seducing him will not be easy.

He brightens a bit at the table when she serves him marinated herring. He likes fish very much. The main course is beef stew, which he also seems to enjoy. They have oranges for dessert, coffee with milk.

"The man's" feelings about marinated fish and beef stew get three whole sentences here. Apparently, they are enough to "brighten" his dark reaction to his lover's (or, perhaps, his wife's) refusal to leave the house. Just by assigning each item on the menu to its own separate sentence (the fish gets two), Beattie makes us see how small and empty are the lives of these characters, when their emotional well-being and a marinated herring are given equal say.

This leveling prose, in which a character's actions are enumerated in the same manner as the lowliest detail of her surroundings, accounts for the bleakness of this passage from "Shifting":

Natalie opened the car door and got behind the wheel and put her hands on it. The wheel was covered with a flaky yellow-and-black cover. She eased it off. A few 
pieces of foam rubber stuck to the wheel. She picked them off. Underneath the cover, the wheel was a dull red.

The actions of the character are listed in the same flat language and conjunctive structure as the physical details of the steering wheel. Nothing is qualified or made relative to anything else. All actions and objects are made equally important-or equally unimportant. Such is the leveling force of the simple subject-verb sentence pattern, repeated without modification or subordination. It is a pattern that creates, sometimes masterfully, the bleak and fragmentary world of Anne Beattie's fiction. It allows her to imply judgments about her characters without uttering a single judgmental word; it forces us to see them as she wants us to. Look at the economy and irony of these sentences about an aging ex-professor trying to make an impression on a former student in "Weekend":

He is at last in touch, he says, being in the country puts him in touch. He is saying it now to Sarah, who has put down her ivory-handled fork to listen to him. He gets up to change the record.

Three sentences, all beginning with "He," one distinguished by the highly visible and revealing detail of putting down the fork, and all three together creating-by means of that same leveling, equalizing force we saw earlier - the biting irony of the last sentence: He says. He is saying. He gets up to change the record.

Another advantage of Beattie's gray, even prose is that it makes all the more visible the rare splash of nonrestrictive detail and the even rarer use of figurative language. (In Secrets and Surprises, I found an average of two metaphors or similes, usually the latter, per story.) A sentence laden with details that might go unnoticed in more generous prose not only calls attention to itself in a Beattie story; it reveals something significant by its very complexity. In a story called "La Petite Danseuse de Quatorze Ans," the daughter of a famous poet is accused by her lover of not loving her father but merely living under his shadow. The surest clue in the entire story that the lover is wrong, that the young woman feels real affection for her father, might be this sentence:

She moved her head to get the picture back: her father, in his baggy slacks and cardigan, smiling down at her, poised on the edge of her bed with his large hands turning the pages of a book as delicately as if the paper were feathers.

If the carefully subordinated details about her father did not alert us to the significance of the sentence in the scheme of the story, then surely the simile at the end would catch our attention. It's the only one in the entire story. If we are reading closely enough, we become convinced of her feelings for her father because she thinks about him in this nostalgically detailed and metaphorical way so uncharacteristic 
of Beattie's fiction. Contrast that sentence about the girl's father with her lover's description of his unhappy home:

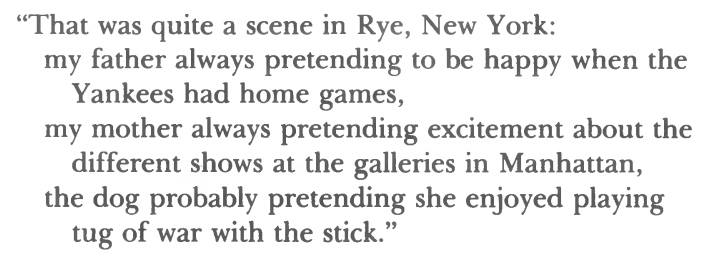

The spatial arrangement is mine, to point out the equalizing force of those parallel phrases about father, mother, and the dog. At first glance, the sentence might look similar to the one recalling the girl's father. There is a main clause identifying what the sentence is about, ending in a colon and followed by a series of details about that subject. But the first sentence takes us from "father" to focus on his face and figure, then moves us closer to see his "large hands," then still closer to see the hands turning the pages of the book, until finally we are close enough to see the pages "as if the paper were feathers." In a rare moment, Beattie moves the reader in close to someone in the story. By contrast, the absolute phrases in the lover's sentence about his family have the same effect as a series of short sentences: father, mother, and dog all pretending, all the same. (In fact, this sentence works in the same way as the quotation from "Why Don't you Dance?" cited earlier). In Carver, as in Beattie, simple and repetitive sentence structure, limited use of detail, and avoidance of figurative language work together to show us a world marked by isolation, barrenness, strict limitation of emotion and experience. They seem to say that the wealth and meaning of human experience are limited to the passing of this moment in the story-this one-nothing else impinges on it, nothing else matters. The moment of the story may not be much, but it is everything.

Contrast their style, their vision, with that of John Cheever, a writer who crams his fiction to the edges with details and digressions, who seems to want to expand the moment, "blow it up to cosmic proportions," connect it with as many wider implications as he can come up with. If Carver and Beattie focus on the moment, to the exclusion of the world "out there" and its wealth of experience, then Cheever tries to bring as much of the world into his fictional moment as he can. His prose is characterized by long, unbroken blocks of print made up of medium-to-long, rambling, cumulative sentences that are laden with modifying phrases of all kinds-participial phrases, appositives, absolutes. The pages of The Stories of John Cheever are riddled with dashesat least four per page by my count-for here is a writer eager to interrupt himself, to pack more into the moment of the story, make it 
bigger, more important, resplendent with metaphor and with cosmic implications. In "The Bella Lingua" he tells us, "here everything was in bloom-fruit trees, mimosa-and the pastures were white with flowers and the vegetable gardens already yielding crops." (Imagine Carver letting us look out the window at some distracting, and fragrant, fruit trees.) And "the people in the streets looked up at this apparition - this fishbowl of elderly Americans-with such incredulity that Uncle George's feelings were hurt." (How likely is it that Beattie would dignify a sight-seeing bus by giving it a metaphor of its own, even one so lowly as a fishbowl?)

Unlike the other two writers, John Cheever's vision is an expansive one. Consequently, his style is like Dickens' in his unabashed digressions, his apparent willingness to expend any number of words, include any number of details, to make sure that we get the whole picture in its largeness and richness and complexity. He sees the world of his fiction as so complex and variable, so necessary down to its most minute detail of character or setting, that he wants to show us everything. He doesn't hesitate to interrupt the second page of the narrative of "The Brigadier and the Golf Widow" to ask,

-and who, after all these centuries, can describe the fineness of an autumn day? One might pretend never to have seen one before, or, to more purpose, that there would never be another one like it. The clear and searching sweep of the sun on the lawns was like a climax of year's lights. Leaves were burning somewhere and the smoke smelled, for all its ammoniac acidity, of beginnings. The boundless blue air was stretched over the zenith like the skin of a drum.

In the "Angel of the Bridge," he doesn't blush to connect lights seen at night from an airplane with the existential concerns of the narrator:

I saw a formation, a trace of light, like the lights that burn along a shore. There was no shore in that part of the world, and I knew I would never know if the edge of the desert or some bluff or mountain accounted for this hoop of light, but it seemed, in its obscurity-and at that velocity and height-like the emergence of a new world, a gentle hint at my own obsolescence, the lateness of my time of life, and my inability to understand the things I often see.

And here is a passage from the opening of "The Geometry of Love" that reveals just what Cheever is up to all the time with his digressions, his dashes, his accumulation of clauses and phrases, his details and metaphors:

It was one of those rainy late afternoons when the toy department of Woolworth's on Fifth Avenue is full of women who appear to have been taken in adultery and who are now shopping for a present to carry home to their youngest child. . . . He hit upon this generalization mostly to give the lassitude of a rainy afternoon some intentness and color. Things were slow at his office.

Beattie and Carver prefer the rain, the lassitude, but Cheever's style infuses even the most mundane moment with metaphysical significance-or at least with intentness and color. He sees the world 
differently than they do. This is not to say that his vision is somehow more "accurate" than theirs. After all, the rain falls, people are isolated, and all the richness of the physical world may as well not be there if a character is unable to enrich him or herself with it. The spare style and sharply limited focus of a Raymond Carver reveal one kind of truth, the expansiveness of a John Cheever another. In either case, the vision of the world is manifest in-and created by-the way the writer uses language, the way he arranges the words that he chooses on the page.

As writers, then, all of us need first to look at the world around us and the people who inhabit it "in order to understand them and fully experience our exchange with them," as John Gardner put it. If we look hard and long enough, perhaps we will begin to see what is important for us to see. And then, if we search carefully (painfully, relentlessly) enough, we may find the right words to make the right sentences to make that vision manifest. We may have, in other words, what they're talking about when they talk about style. 